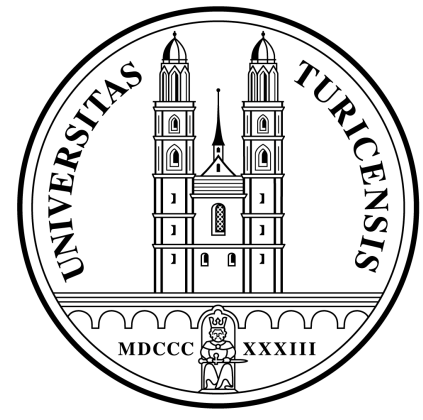

Institute for Empirical Research in Economics

University of Zurich

Working Paper Series

ISSN 1424-0459

published in: The Economic Journal, 110 (466, October), 2000, pp. 918-938

Working Paper No. 15

Happiness, Economy and Institutions

Bruno S. Frey and Alois Stutzer

July 1999 
1. November 1999

\title{
HAPPINESS, ECONOMY AND INSTITUTIONS
}

\author{
by
}

\author{
Bruno S. Frey and Alois Stutzer \\ (University of Zurich) ${ }^{*}$
}

Summary: A cross-regional econometric analysis suggests that institutional factors in the form of direct democracy (via initiatives and referenda) and of federal structure (local autonomy) systematically and sizeably raise self-reported individual well-being. This positive effect can be attributed to political outcomes closer to voters' preferences, as well as to the procedural utility of political participation. Moreover, the results of "standard" microeconometric well-being functions previously published for other countries are generally supported. Unemployment has a strongly depressing effect on happiness. A higher income level raises happiness, however, only to a small extent. (90 words)

JEL classification: D60, D72, H10, I31

Keywords: subjective well-being, institutions, direct democracy, unemployment

\footnotetext{
${ }^{*}$ Bruno S. Frey is professor, and Alois Stutzer is research assistant, of economics at the University of Zurich. Address: Institute for Empirical Economic Research, University of Zurich, Blümlisalpstrasse 10, 8006 Zurich, Tel.: 0041-1-634 37 28, Fax: 0041-1-634 49 07, E-mail: bsfrey@iew.unizh.ch, astutzer@iew.unizh.ch. We thank Matthias Benz, Iris Bohnet, Rafael Di Tella, Richard Easterlin, Reiner Eichenberger, Lars Feld, Douglas Hibbs, Rod Hill, Reto Jegen, Marcel Kucher, Robert Lane, Robert Leu, Yew-Kwang Ng, Felix Oberholzer-Gee, Karl-Dieter Opp, Andrew Oswald, Marcel Savioz, Jean-Robert Tyran, Ruut Veenhoven and Rainer Winkelmann for helpful remarks, and Lorenz Götte for providing econometric support.
} 
The recent Controversy on "Economics and Happiness" in the November 1997 issue of the Economic Journal ${ }^{1}$ awakened, or at least raised, economists' awareness that "happiness" is an interesting and empirically relevant concept for our discipline. Oswald (1997) demonstrates with data for the United States and 12 countries of the European Union that (1) money buys happiness, but that the effect is small, and sometimes statistically insignificant; (2) unemployment makes people very unhappy, over and above the concomitant income loss (as in Clark and Oswald, 1994; Winkelmann and Winkelmann, 1998). Furthermore, happiness ${ }^{2}$ is "high among those who are married, on high income, women, whites, the well-educated, the self-employed, the retired, and those looking after the home. Happiness is apparently U-shaped in age (minimising around the 30s)" (Oswald, 1997, p. 1823).

This paper argues that institutional conditions in the form of the extent and form of democracy have systematic and sizeable effects on individual well-being, in addition to demographic and economic factors. Using recent interview data from 6,000 residents of Switzerland, we show that individuals are cet. par. happier, the better developed the institutions of direct democracy are in their area of residence. This also applies to a second institution, the degree of government decentralisation (federalism). Finally, we are able to support some of the earlier results for other countries and periods with new data also based on a survey with a large sample size. In particular, we find that the unemployed are to a great extent less happy than employed persons, and that a higher household income level only raises happiness to a small extent.

\section{Determinants of Happiness}

It is useful to differentiate three sets of sources of individual well-being:

(1) Personality and demographic factors. Several of the above mentioned variables belong to this category. They have for many decades been extensively studied by psychologists. Diener, Suh, Lucas and Smith (1999) provide a survey, extending and bringing up to date the earlier surveys by Wilson (1967) and Diener (1984). Monographs are by Argyle (1987) and Myers (1993).

\footnotetext{
${ }^{1}$ Edited by Dixon (1997), with contributions by Oswald (1997), Frank (1997) and Ng (1997).

${ }^{2}$ Happiness is, for simplicity's sake, in the following interchangeably used with the terms satisfaction with life and reported subjective well-being. We are aware that subjective well-being is a scientific concept rather than a specific measure of well-being, and that it contains affective components i.e. mood and emotions like joy, happiness or depression as well as cognitive evaluations of life satisfaction (see e.g. Lucas et al., 1996). However, most of these measures are substantially correlated. In the current study we use a measure of satisfaction with life.
} 
(2) Micro- and macroeconomic factors. An early study of the effect of income on happiness is due to Easterlin (1974, see also 1995), but psychologists have also undertaken substantial work in this direction (see the survey by Diener and Oishi, 1999). In most nations, those individuals belonging to the highest income group report somewhat higher subjective wellbeing than persons with low income. This relationship is, however, of small size and not robust. The often dramatic increase in per capita incomes in recent decades has not raised happiness in general; the national indices for subjective well-being have virtually remained flat over time. In contrast to findings within a nation, per capita income levels and happiness are more strongly positively related across nations (for further discussion see also Kenny, 1999).

The influence of the other two major economic variables, unemployment and inflation, is clear-cut. Unemployment is correlated with substantial unhappiness. As the income level is kept constant, that influence is not due to lower revenue but to non-pecuniary stress. In terms of a trade-off, "most regression results imply that an enormous amount of extra income would be required to compensate people for having no work" (Oswald, 1997, p. 1821). Individuals also have a strong aversion towards inflation and are prepared to carry significant cost to evade it: "one percentage point of inflation corresponds to a well-being cost of approximately two per cent of the level of income per capita" (Di Tella, MacCulloch and Oswald, 1997, p. $18)^{3}$

(3) The third set of influences on happiness relates to the institutional (or constitutional) conditions in an economy and society, of which democracy and federalism are of greatest importance. To our knowledge, the impact of the extent and design of democratic and federal institutions on subjective well-being has, at best, been alluded to, but has never been extensively analysed.

\footnotetext{
${ }^{3}$ These results provide welcome and important insights into a broader effort to empirically measure individuals' reaction to, and therewith evaluation of, the influence of macro-economic variables. Other approaches are (see more extensively Frey, 1991): (i) retreat from society, or at least from the official economy, e.g. by working in the shadow sector (e.g. Cowell, 1990; Thomas, 1992); (ii) popularity and election functions (surveys are given e.g. in Nannestad and Paldam, 1994; Schneider and Frey, 1988); (iii) political preference functions derived from the behaviour of governments and central banks (see the survey and critique in Makin, 1976); (iv) non-conventional political participation ranging from demonstrations to publicly motivated strikes (see e.g. Hibbs, 1976; Opp, 1989); and (v) use of force, i.e. all sorts of revolutions and coups d'état (e.g. Hibbs, 1973; Opp, Voss and Gern, 1995). The wellbeing functions, together with popularity and election functions, belong to the best defined and statistically most advanced efforts to measure the absolute and relative importance of macro-economic conditions for individuals.
} 
The determinants of happiness are usually investigated under the assumptions that subjective well-being is cardinally measurable and interpersonally comparable; i.e. two claims economists are likely to be sceptical about. To circumvent reservations in regard to a cardinal interpretation of subjective variables, it is often possible to treat the subjective data qualitatively in econometric analyses. In contrast, whether people associate the same degree of subjective experience with a certain score on a ladder for life satisfaction is more difficult to assess. However, there is a lot of indirect evidence that cardinalism and interpersonal comparability are practically much less of a problem than theoretically. The measures of subjective well-being have high consistency, reliability and validity. Happy people are e.g. more often smiling during social interactions (Fernández-Dols and Ruiz-Belda, 1995), are rated as happy by friends and family members (Sandvik, Diener and Seidlitz, 1993), as well as by spouses (Costa and McCrae, 1988). Furthermore, the measures of subjective well-being have a high degree of stability over time (Headey and Wearing, 1989). But there is, of course, room for methodological concerns (e.g. Diener et al., 1999: pp. 277-8). Moreover, as will be demonstrated in this paper, the main use of happiness measures is not to compare levels, but rather to seek to identify the determinants of happiness.

\section{Effects of Institutions on Happiness}

Most political institutions tend to be stable over time, so that a cross-sectional analysis of subjective well-being is appropriate. This has been done between countries (e.g. by Veenhoven 1993; 1999, on the basis of the World Values Survey, and by Diener et al., 1995). ${ }^{4}$ It is, of course, difficult to isolate the effect of particular institutions on reported individual well-being because the countries differ in a great variety of aspects. This problem is less acute for institutional variations within a (federal) country. As far as we know, this is the first paper using cross-regional variations in a happiness study. Cross-regional procedures have been used with good results to account for the share of government expenditures between governmental units

\footnotetext{
${ }^{4}$ Considering institutional differences, there is, methodologically, a close relation of this research to cross-country growth analysis (see e.g. Barro, 1997). However, this literature has not yet been incorporated into happiness research. There is also a relation to well-being measurement in research on economic development. Dasgupta (1993), for example, provides a measure of well-being that includes standard of living as well as indices of political and civil liberties.
} 
with different degrees of direct participation possibilities for its citizens (as done for the United States, ${ }^{5}$ as well as for Switzerland ${ }^{6}$ ).

There are two major reasons why a higher extent of direct political participation possibilities, or more strongly developed institutions of direct democracy (in particular via popular referenda and initiatives) can be expected to raise citizens' subjective well-being (Cronin, 1989; Budge, 1996, or for an economic analysis Frey, 1994).

Firstly, due to the more active role of the citizens, (professional) politicians are better monitored and controlled. Government activity, i.e. public outlays as well as the many other decisions by the government, are closer to the wishes of the citizenry. ${ }^{7}$ As a consequence, satisfaction with government output is reflected in a higher level of overall well-being.

Secondly, the institutions of direct democracy extend the citizens' possibilities to get involved in the political process. Experimental evidence (e.g. Tyler, 1990; Bohnet and Frey, 1999) suggests that this procedural effect is independent of the outcome of the political activity itself.

Federal decentralisation, and, in particular, local autonomy, is another constitutional element which can be hypothesised to positively affect citizens' happiness. Political decision making in municipalities is closer to relevant information about residents' preferences and also closer to direct control by its citizens (Frey and Eichenberger, 1999).

\section{Data for Econometric Analysis}

Our empirical work is based on the survey results of more than 6,000 residents of Switzerland for the year 1992, collected by Leu, Burri and Priester (1997). ${ }^{8}$ The dependent variable called "happiness" is based on the answers to the following question: "How satisfied are you with your life as a whole these days?". Simultaneously, the respondents were shown a table with a 10 point scale of which only the two extreme values ("completely dissatisfied" and "completely satisfied") were verbalised. The survey found a high general life satisfaction in Switzerland with an average

\footnotetext{
${ }^{5}$ See e.g. Matsusaka (1995) or Rueben (forthcoming) for general government expenditure, or Santerre (1989, 1993) for public education expenditures.

6 See e.g. Schneider and Pommerehne (1983) and Feld and Kirchgässner (1996) for general government expenditures. The latter also study the effect on self-financing ratios, taxes, and debt. Pommerehne and Weck (1996) and Frey (1997) analyse the effect on tax evasion, and Feld and Savioz (1997) on per capita gross domestic product.

7 This statement is supported by considerable empirical (econometric) evidence, e.g. Pommerehne (1978, 1990) or Gerber (1999).

${ }^{8}$ The survey data were collected to investigate the problem of poverty in Switzerland. Information is from personal interviews and tax statistics.
} 
of 8.2 out of 10 points. No fewer than $29 \%$ of the interviewees reported a satisfaction level of 10 ("completely satisfied"), $17 \%$ of 9 , and $27 \%$ of 8 . The lower end of the happiness-scale, "completely dissatisfied" (score 1), score 2 and score 3 , were indicated only by $0.4 \%, 0.5 \%$, and $0.9 \%$, respectively. As these categories of great unhappiness are thinly populated, they are aggregated, leaving us with eight happiness categories. ${ }^{9}$

In this paper, as a major explanatory variable, we focus on the institutionalised rights of individual political participation, which vary between the 26 Swiss cantons. Due to the federal structure of Switzerland, major competences are kept by the cantons (states). As on the national level, there exist direct democratic instruments besides representative democratic parliaments and governments. The most important direct democratic instruments in cantons are the popular initiative to change the canton's constitution or laws, a compulsory and optional referendum to prevent new laws, or the changing of existing laws, and optional financial referenda to prevent new state expenditure. Citizens' access to these instruments differ from canton to canton. Thus, for example, the number of signatures required to launch an initiative or an optional referendum, or the time span within which the signatures have to be collected, varies. The referendum on public expenditures may be launched at different levels of additional outlays. For the 26 cantons, we constructed an index designed to reflect the extent of direct democratic participation possibilities (for details of the index construction, see the Appendix). This index is defined using a six point scale with 1 indicating the lowest, and 6 the highest degree of participation possibilities for the citizens. Figure 1 provides an overview.

The purpose of our estimate is to show that the extent of direct democratic participation possibilities exerts a statistically significant, robust and sizeable effect on happiness over and above the demographic and economic determinants so far taken into account in the literature.

We also intend to demonstrate that institutional factors are relevant for happiness in general by analysing the impact of federalism. The division of the competences between communities and the cantonal government reflects the federal structure of a canton or, from the municipalities' point of view, their autonomy. The extent of local autonomy is measured by an index (Ladner 1994). The index over the 26 cantons is based on survey results. Chief local administrators in 1856 Swiss municipalities were asked to report how they perceive their local autonomy on a 10 point scale, with one indicating "no autonomy at all", and 10 "very high" communal autonomy.

\footnotetext{
${ }^{9}$ The regrouping of the lowest categories does not change the qualitative results.
} 


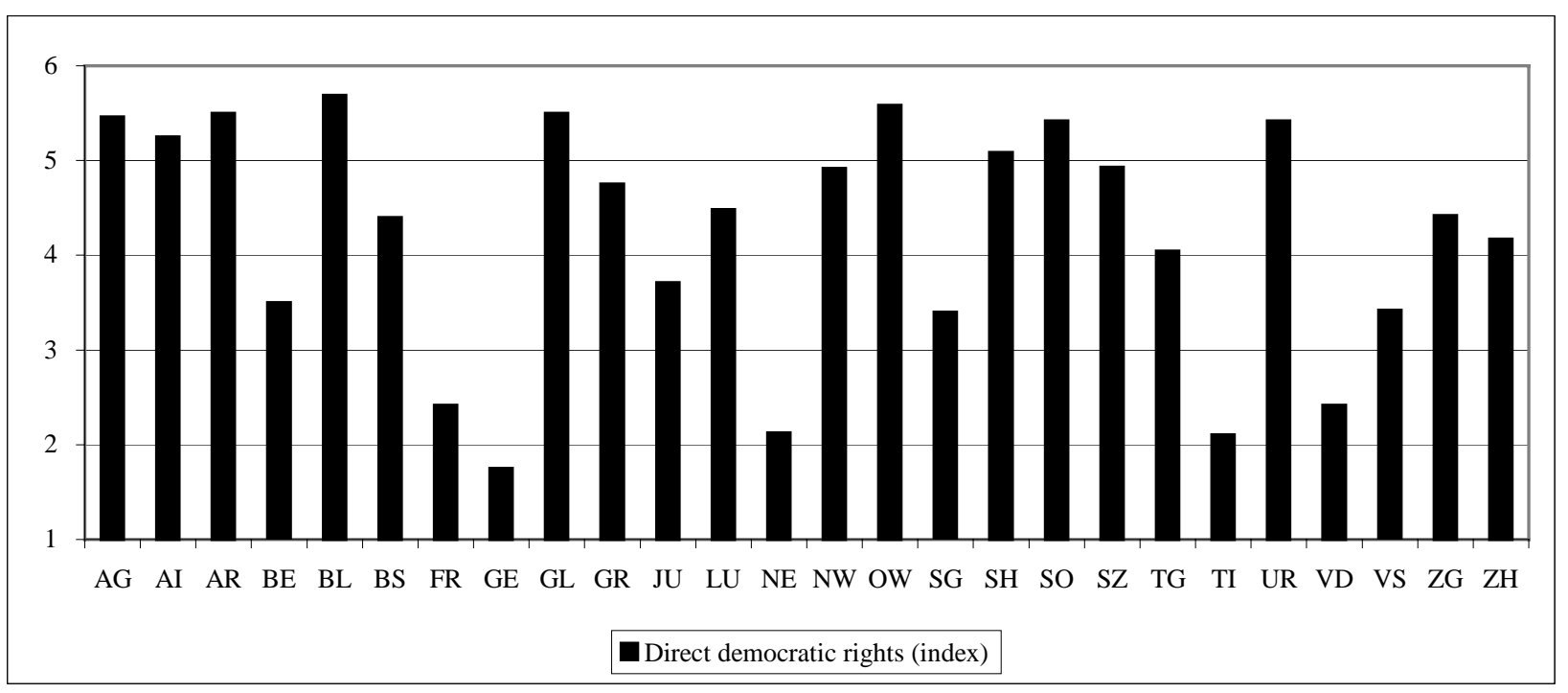

Fig. 1. Direct democracy in Swiss cantons

The figure shows the degree of direct democratic participation possibilities in the 26 Swiss cantons, namely Aargau (AG), Appenzell i. Rh. (AI), Appenzell a. Rh. (AR), Bern (BE), Basel Land (BL), Basel Stadt (BS), Fribourg (FR), Genève (GE), Glarus (GL), Graubünden (GR), Jura (JU), Luzern (LU), Neuchâtel (NE), Nidwalden (NW), Obwalden (OW), St. Gallen (SG), Schaffhausen (SH), Solothurn (SO), Schwyz (SZ), Thurgau (TG), Ticino (TI), Uri (UR), Vaud (VD), Valais (VS), Zug (ZG) and Zürich (ZH).

The estimation equations regress the indices of individual happiness on three sets of determinants:

\section{1) Demographic variables}

They describe the personal attributes of the respondents and comprise

- age. Six age groups are explicitly accounted for, ranging from 30 years to 80 years and older (the constant term includes the reference group "people younger than 30");

- gender (male/female);

- citizenship (national/foreigner);

- extent of formal education (middle/high education) (reference group are "people with low education");

- family setting (single woman or man; couple with children; single parent, other, collective household) (reference group are "couple") and

individual employment status (self-employed or employee in one's own firm; housewife or houseman; other) (reference group are "employed"). 


\section{2) Economic variables}

Two influences are considered:

- Unemployment (the constant term includes the reference group “employed”);

- Income situation of the household (equivalence income). Total household income after taxes, social security expenditure, interests on debts and maintenance is divided through the equivalence scale of the Swiss conference for public assistance. Four income groups are explicitly distinguished, ranging from Sfr. 2,000 to Sfr. 5,000 per month and more (reference group are "people with a lower equivalence income than Sfr. 2,000").

The above two sets of variables ${ }^{10}$ are used as controls. While they are of obvious interest in themselves, they mainly serve to isolate the unbiased influence of the third set of variables.

\section{3) Political institutions}

The variables included in the estimation models are

- $\quad$ an index for direct democratic rights and

- $\quad$ an index for the extent of local (communal) autonomy.

The latter variables refer to the 26 cantons in Switzerland. The structure of Swiss cantons, however, does not only differ in respect of direct democracy and federal organisation but also, e.g., in respect of urbanisation. Therefore, to control for further regional differences, we include five variables for the size of community and seven variables for the type of community in the estimation equations.

\section{Results and Discussion of Econometric Analysis}

We present the results of our econometric analysis in seven separate sections. In sections 4.1 to 4.4, we discuss the effects of the three sets of demographic, economic and institutional variables on happiness. In section 4.5 we perform several tests of robustness which support our argumentation. Finally, sections 4.6 and 4.7 indicate who benefits from direct democracy and that the benefits can be attributed to a favourable outcome as well as to a favourable direct democratic process itself.

\footnotetext{
${ }^{10}$ We cannot address the issue of how inflation affects reported subjective well-being, as our data set is a crosssection of individuals.
} 


\subsection{Microeconometric Happiness Functions}

Table 1 presents the estimated coefficients and marginal effects of two microeconometric happiness functions, taking into account demographic and economic determinants as well as the institutional variable direct democratic rights. In the first equation, a weighted least squares model is estimated. In the second one, a weighted ordered probit model is used in order to exploit the ranking information contained in the originally scaled dependent variable. The weighting variable that is applied allows representative results on the subject level for Switzerland. ${ }^{11}$ Throughout the paper, we use a robust estimator of variance because random disturbances are potentially correlated within groups or clusters. Here, dependence refers to residents of the same canton. $^{12}$

The estimation results show statistically significant effects of several demographic factors, all the economic variables and, most importantly, the institutional determinant on individual happiness. The least squares estimation that treats happiness as a cardinal variable offers qualitatively very similar results to the ordered probit model, i.e the results are robust in regard to the estimation method. The coefficients of the former model can be interpreted in a simple way: people belonging to a certain category on average report happiness scores deviating from that of the reference group on the scale of the coefficient. ${ }^{13}$ (For example, people of middle education on average report 0.23 score points more satisfaction with life than people with lower education.) In the ordered probit estimation, a positive coefficient indicates that the probability of stating happiness greater than or equal to any given level increases. The marginal effect indicates the change in the share of persons belonging to a stated happiness level when the independent variable increases by one unit. ${ }^{14}$ In the case of dummy variables, the marginal effect is evaluated in regard to the reference group. For simplicity, only the marginal effects for the extreme value of

\footnotetext{
11 Due to clustering and stratification in contrast to pure random sampling, weights are necessary to get approximately unbiased point estimates. Weights are proportional to the inverse of the probability of being sampled. In addition, the weights are adjusted to the demographic structure in 1992.

12 Ignoring the clustering in the estimation model is likely to produce downward biased standard errors, due to the effects of aggregate variables on individual data (Moulton 1990). To get unbiased standard errors for the aggregate variable "direct democratic rights", the 26 cantons are used as sampling units. (Ignoring clustering, a t-value of 5.079 instead of 3.054 is estimated in Table 1.) Apart from clustering, stratification also has a downward effect on standard errors. The significance levels take into account the bias due to stratification, i.e. $\mathrm{p}<0.01$ for $|\mathrm{t}|>2.88,0.01<\mathrm{p}<0.05$ for $2.17<|\mathrm{t}|<2.88$ and $0.05<\mathrm{p}<0.10$ for $1.81<|\mathrm{t}|<2.17$.

${ }^{13}$ For a continuous variable, the coefficient indicates the increase in happiness scores when the independent variable increases by one unit.

14 Alternatively, the marginal effect indicates the change of the probability belonging to a stated happiness level when the independent variable increases by one unit.
} 
Table 1.

Direct Democracy and Satisfaction with Life in Switzerland in 1992

\begin{tabular}{|c|c|c|c|c|c|}
\hline \multirow[b]{2}{*}{ Variable } & \multicolumn{2}{|c|}{$\begin{array}{l}\text { Weighted least squares } \\
\text { Std. err. adjusted to } \\
\text { clustering in } 26 \text { cantons }\end{array}$} & \multicolumn{3}{|c|}{$\begin{array}{l}\text { Weighted ordered probit } \\
\text { Std. err. adjusted to } \\
\text { clustering in } 26 \text { cantons }\end{array}$} \\
\hline & Coefficient & t-value & Coefficient & t-value & $\begin{array}{l}\text { Marginal } \\
\text { effect } \\
\text { (score 10) }\end{array}$ \\
\hline \multicolumn{6}{|l|}{ (1) Demographic variables } \\
\hline Age $30-39$ & -0.145 & -1.064 & -0.079 & -0.865 & -0.027 \\
\hline Age $40-49$ & -0.031 & -0.270 & -0.008 & -0.106 & -0.003 \\
\hline Age $50-59$ & -0.177 & -1.898 & -0.081 & -1.275 & -0.027 \\
\hline Age $60-69$ & $0.258 *$ & 2.349 & $0.206 * *$ & 2.903 & 0.073 \\
\hline Age $70-79$ & $0.389 *$ & 2.866 & $0.295 * *$ & 3.401 & 0.106 \\
\hline Age 80 and older & $0.341 *$ & 2.519 & $0.273^{* *}$ & 2.968 & 0.099 \\
\hline Female & 0.039 & 0.765 & 0.043 & 1.211 & 0.015 \\
\hline Foreigner & $-0.450 * *$ & -5.146 & $-0.284 * *$ & -5.048 & -0.091 \\
\hline Middle education & $0.232 * *$ & 4.504 & $0.113^{* *}$ & 3.143 & 0.039 \\
\hline High education & $0.266^{* *}$ & 3.387 & $0.119 *$ & 2.472 & 0.042 \\
\hline Single woman & $-0.373 * *$ & -6.238 & $-0.258 * *$ & -6.294 & -0.083 \\
\hline Single man & $-0.295^{*}$ & -2.557 & $-0.174 *$ & -2.589 & -0.057 \\
\hline Couple with children & -0.090 & -1.440 & -0.068 & -1.777 & -0.023 \\
\hline Single parent & $-0.614 * *$ & -3.312 & $-0.372 * *$ & -3.602 & -0.113 \\
\hline Other private household & -0.170 & -1.499 & -0.128 & -1.664 & -0.042 \\
\hline Collective household & $-0.646^{* *}$ & -3.171 & $-0.413 * *$ & -3.432 & -0.124 \\
\hline Self-employed & 0.058 & 0.796 & 0.072 & 1.413 & 0.025 \\
\hline Housewife & $0.155^{(*)}$ & 2.065 & $0.123 *$ & 2.463 & 0.043 \\
\hline Other employment status & $-0.216^{(*)}$ & -2.110 & $-0.129^{(*)}$ & -1.911 & -0.044 \\
\hline \multicolumn{6}{|l|}{ (2) Economic variables } \\
\hline Unemployed & $-1.574 * *$ & -5.768 & $-0.841 * *$ & -5.814 & -0.211 \\
\hline Equiv. income Sfr. 2,000-3,000 & $0.156^{*}$ & 2.697 & $0.084 *$ & 2.199 & 0.029 \\
\hline Equiv. income Sfr. 3,000-4,000 & $0.243^{* *}$ & 3.747 & $0.143^{* *}$ & 3.169 & 0.050 \\
\hline Equiv. income Sfr. 4,000-5,000 & $0.399 * *$ & 5.646 & $0.258^{* *}$ & 5.382 & 0.092 \\
\hline Equiv. income Sfr. 5,000 and more & $0.302 * *$ & 4.938 & $0.192 * *$ & 4.277 & 0.068 \\
\hline \multicolumn{6}{|l|}{ (3) Institutional variable } \\
\hline Direct democratic rights & $0.116^{* *}$ & 2.907 & $0.082 * *$ & 3.054 & 0.028 \\
\hline Observations & 6134 & & 6134 & & \\
\hline $\mathrm{R}^{2}$ & 0.091 & & & & \\
\hline Prob $>$ F & 0.049 & & 0.001 & & \\
\hline
\end{tabular}

Notes: Dependent variable: level of satisfaction on an eight point scale (scores of 1,2 and 3 were aggregated). White estimator for variance. In the reference group are 'people younger than 30', 'men', 'Swiss', 'people with low education', 'couples', 'employed people' and 'people with a lower equivalence income than Sfr. 2,000'. Additional control variables (not shown) for size of community ( 5 variables) and type of community ( 7 variables). Significance levels: ${ }^{(*)} 0.05<\mathrm{p}<0.10, * 0.01<\mathrm{p}<0.05, * * \mathrm{p}<0.01$.

Data source: Leu, Burri and Priester (1997). 
very high happiness (score 10) are shown in table 1. (For example, being unemployed rather than employed lowers the probability of a person stating that he or she is completely satisfied by 21.1 percentage points.)

\subsection{Demographic and Economic Factors of Life Satisfaction}

Compared to the reference group, people older than 60 are happier. Women are not happier than men if the different employment status is considered separately. Furthermore, foreigners are subject to a significantly lower probability of reaching high happiness scores compared to the Swiss. People with higher education report significantly higher subjective well-being. Couples without children are happier than singles, single parents and people living in collective households.

Among the economic variables, higher income correlates with higher happiness in a statistically significant way. However, the differences in subjective well-being are rather small. Consider, for example, the highest income group with a monthly equivalence income above Sfr. 5,000. Compared to persons with low income, only a 6.8 percentage points larger share reports being "completely satisfied". As already alluded to above, unemployment has a very large negative influence on individual well-being. The coefficient of this variable is largest in comparison to the other significant coefficients mentioned.

The demographic and economic variables in the happiness equation thus yield very similar results for Swiss data as were previously found by Oswald (1997) and Di Tella et al. (1997) for other countries, in particular the highly significant and large negative effect of being unemployed, and the small positive effect of income. ${ }^{15}$

\subsection{The Effect of Direct Democracy on Subjective Well-being}

Table 1 also shows the results for one of the institutional variables. The index for direct democratic rights has a highly significant positive effect on happiness. An increase in the index of direct democracy by one point raises the share of persons indicating very high satisfaction with life by 2.8 percentage points. This result is consistent with our hypothesis that the institutions of direct democracy raise the reported subjective well-being. In addition, the effect itself is sizeable: (i) The marginal effect of direct democratic rights on happiness is as large as the effect of living

\footnotetext{
${ }^{15}$ Part of the correlation observed can, of course, be explained by reverse causation. For happy people, it is easier to find a partner. They probably less often lose their job and get jobs where they earn more money.
} 
in the second-bottom (Sfr. 2,000-3,000) instead of the bottom income category (< Sfr. 2,000). (ii) The effect is even larger when the full range of the institutional variable is considered, i.e. individuals in canton Basel Land (with the highest democracy index of 5.69) are compared to citizens in canton Geneva (with the lowest direct participation rights of 1.75). The former state with an 11 percentage points higher probability that they are completely satisfied. (iii) The improvement affects everybody, i.e. the institutional factor is important in an aggregate sense. In comparison, getting a job "only" raises the subjective well-being of the unemployed.

Do happy people choose direct democratic institutions? Or does the causality between direct democracy and subjective well-being work in reverse? Direct democratic participation possibilities in the form of referenda and initiatives in Switzerland started to develop in the middle of the $19^{\text {th }}$ century. The adoption of some of the instruments of direct popular participation reflects the spread of the spirit and ideas behind the American and the French revolutions. Equally important were political movements within the citizenry. Citizens fought for direct democratic instruments to gain political power against arbitrary decisions by parliaments and the influence of industrial pressure groups on these authorities in the cantons (see e.g. Kölz, 1998). This historic perspective suggests that the democratic institutions are not simply the result of happy and satisfied citizens. Especially during the last decades, institutional conditions in Swiss cantons have been quite stable, ${ }^{16}$ which suggests that causality runs unambiguously from direct democratic rights to satisfaction with life.

\subsection{The Effect of Federalism on Happiness}

Table 2 focuses on federalism in the sense of "devolution" as a second important political institution hypothesised to raise happiness. Therefore, the variable "local autonomy" is added to the demographic and economic factors in the happiness equation. (For simplicity, only the coefficients for variables of interest are shown. However, they indicate the partial effects controlling for the demographic and economic variables included in table 1. Moreover, the coefficients of the latter variables are almost unaltered. ${ }^{17}$ ) The estimate reveals a statistically significant positive effect on subjective well-being. For local autonomy, the share of persons indicating very high happiness increases by 3.3 percentage points, compared to a situation in which their commune is one index point less autonomous vis-à-vis their canton.

\footnotetext{
16 The Spearman rank order correlation of the index for direct democratic rights between 1970 and 1996 is 0.803 .

17 The full estimation results for all the equations are available from the authors on request.
} 
Local autonomy and direct democracy are not independent of each other, of course. On the one hand, direct democracy fosters federal structures on the national and state level because citizens in contrast to politicians - are most interested in strong federalism (Blankart, 1998). On the other hand, the persons bearing the costs and benefits of government action are better identifiable in a decentralized system. Direct legislation, therefore, leads to better political decisions and thus preserves direct democracy. As a result, the indices for direct democratic rights and local autonomy are highly correlated $(r=0.605)$. This makes it impossible to clearly separate the effects of the two variables in one model. The second equation in table 2 jointly includes the two constitutional factors, local autonomy and direct democratic rights. The coefficient for the variable measuring federalism is roughly one third as large as when it is taken alone and it loses its significance. The index for direct democracy has only a slightly smaller marginal effect on life satisfaction than estimated in table 1 , namely 0.024 instead of $0.028 .^{18}$ Direct democracy and federalism in Switzerland thus seem to be complements rather than economic substitutes. Local autonomy is one of the several "transmission mechanisms" of direct democracy's beneficial effects. In the following paragraphs, we therefore focus on direct democracy.

Table 2.

Local Autonomy and Satisfaction with Life in Switzerland in 1992

\begin{tabular}{|c|c|c|c|c|c|c|}
\hline \multirow[b]{2}{*}{ Variable } & \multicolumn{3}{|c|}{$\begin{array}{l}\text { Weighted ordered probit } \\
\text { Std. err. adjusted to } \\
\text { clustering in } 26 \text { cantons }\end{array}$} & \multicolumn{3}{|c|}{$\begin{array}{l}\text { Weighted ordered probit } \\
\text { Std. err. adjusted to } \\
\text { clustering in } 26 \text { cantons }\end{array}$} \\
\hline & Coefficient & t-value & $\begin{array}{c}\text { Marginal } \\
\text { effect } \\
\text { (score 10) }\end{array}$ & Coefficient & t-value & $\begin{array}{c}\text { Marginal } \\
\text { effect } \\
\text { (score } 10) \\
\end{array}$ \\
\hline (1) Demographic variables & yes & & & yes & & \\
\hline (2) Economic variables & yes & & & yes & & \\
\hline \multicolumn{7}{|l|}{ (3) Institutional variables } \\
\hline Local autonomy & $0.098 * *$ & 2.913 & 0.033 & 0.036 & 1.005 & 0.012 \\
\hline Direct democratic rights & & & & $0.071 *$ & 2.317 & 0.024 \\
\hline Observations & 6134 & & & 6134 & & \\
\hline Prob $>\mathrm{F}$ & 0.003 & & & 0.001 & & \\
\hline
\end{tabular}

Notes: see table 1.

Data sources: Ladner (1994), Leu, Burri and Priester (1997).

\footnotetext{
${ }^{18}$ In an adjusted Wald test, the two institutional factors together are significant on the two percent level $($ Prob $>\mathrm{F}=$ $0.0155)$.
} 


\subsection{Sensitivity Analysis}

To check the reliability of the results, several tests of robustness are performed: (i) the influence of outliers is analysed with a DFBETA-test; (ii) an ordinal measure instead of a cardinal one is applied for the extent of direct democratic rights; (iii) the effect of the four sub-indices on happiness is tested; and finally (iv) four different aggregate control variables are used.

To investigate whether the positive correlation between direct democracy and happiness is largely driven by a single canton, a DFBETA-test is performed. A two-step approach is chosen. In the first step, a further weighted ordered probit model with a dummy variable for each canton is estimated. In preparation for the second step, the estimated coefficients are correlated with the index for direct democratic rights. Due to the problem of heteroskedasticity, a weighted least square regression is estimated. ${ }^{19}$ The result is as follows (t-values in parentheses):

fixed effects for cantons $=-0.275^{*}+0.079^{* *} \mathrm{x}$ index for direct democratic rights,

$$
(-2.653) \quad(3.041)
$$

number of observations $=26$ and adjusted $\mathrm{R}^{2}=0.248 .{ }^{20}$

With the same estimation model, 26 equations are estimated, with a different canton omitted each time. For each equation, the estimated coefficient for the institutional variable is subtracted from the coefficient in the base equation (0.079) and divided by the estimated standard error. The resulting value is called DFBETA. If it is greater than 1.96 in absolute value, the omitted canton has a significant influence on the coefficient of the institutional variable. Table III in the appendix shows that no observations from one single canton have a significant influence. The maximum value of the DFBETA statistic is -0.829 for canton Ticino. ${ }^{21}$ This shows that the positive effect of direct democracy on happiness is not the result of an influential outlier.

The applied measure for the extent of direct democratic participation possibilities is constructed as a cardinal index. However, the same results should be obtained if ordinal dummy variables for direct democratic rights are constructed. To test this claim, cantons were classified into three groups: cantons with an index score lower than four have low direct democratic rights, cantons with an index between four and five have medium direct democratic rights and cantons with an

\footnotetext{
${ }^{19}$ Heteroskedasticity arises because the coefficients for the canton's dummy variables are accounted from samples with largely different size. Therefore, the weighting variables contain the number of observations per canton.

${ }^{20}$ The results for ordinary least squares are as follows: fixed effects for cantons $=-0.402 *(-2.277)+0.125 * *(3.104)$ $\mathrm{x}$ index for direct democratic rights, with adjusted $\mathrm{R}^{2}=0.257$.
} 
index score above five are ranked highly, with respect to direct democratic rights. The two dummy variables for cantons with a medium and a high ranking are included in the estimation equation presented in table 3. As can be seen, satisfaction with life is higher for people living in cantons with medium and high direct democratic rights. The significant coefficient for the top category is 0.179 . (The reference group are people who live in cantons, with low direct democratic rights).

The variable for direct democratic participation possibilities is a non-weighted composite index (see Appendix). This aggregation leaves behind various substitutive and complementary relationships between the single components of the index. Nevertheless, the components can be evaluated by themselves. However, the analysis faces the problem of multicorrelation. ${ }^{22}$ Therefore, the influence of each component is evaluated separately (see table 3 ).

Table 3.

Sensitivity Analysis: Ordinal Variable and Sub-Indices for Direct Democracy

\begin{tabular}{|c|c|c|c|c|c|}
\hline \multirow[b]{2}{*}{ Variable } & \multicolumn{5}{|c|}{ Weighted ordered probit, std. err. adjusted to clustering in 26 cantons } \\
\hline & (1) & (2) & (3) & (4) & $(5)$ \\
\hline (1) Demographic variables & yes & yes & yes & yes & yes \\
\hline (2) Economic variables & yes & yes & yes & yes & yes \\
\hline \multicolumn{6}{|l|}{ (3) Institutional variables } \\
\hline $\begin{array}{l}\text { Direct democratic rights } \\
\text { index between } 4 \text { and } 5\end{array}$ & $\begin{array}{l}0.114 \\
(1.733)\end{array}$ & & & & \\
\hline $\begin{array}{l}\text { Direct democratic rights } \\
\text { index above } 5\end{array}$ & $\begin{array}{l}0.179^{*} \\
(2.308)\end{array}$ & & & & \\
\hline $\begin{array}{l}\text { Index for constitutional } \\
\text { initiative }\end{array}$ & & $\begin{array}{l}0.060^{*} \\
(2.311)\end{array}$ & & & \\
\hline $\begin{array}{l}\text { Index for legislative } \\
\text { initiative }\end{array}$ & & & $\begin{array}{l}0.072 * * \\
(2.891)\end{array}$ & & \\
\hline $\begin{array}{l}\text { Index for legislative } \\
\text { referendum }\end{array}$ & & & & $\begin{array}{l}0.042^{(*)} \\
(1.945)\end{array}$ & \\
\hline $\begin{array}{l}\text { Index for financial } \\
\text { referendum }\end{array}$ & & & & & $\begin{array}{l}0.059 * * \\
(3.075)\end{array}$ \\
\hline Observations & 6134 & 6134 & 6134 & 6134 & 6134 \\
\hline Prob $>\mathrm{F}$ & 0.001 & 0.001 & 0.002 & 0.004 & 0.004 \\
\hline
\end{tabular}

Notes: see table 1. Coefficients with significance levels. T-values in parentheses. Reference group in equation 1 are cantons with direct democratic rights lower than 4.

Data sources: Leu, Burri and Priester (1997) and Swiss Federal Statistical Office (1997).

All four sub-indices have a significantly positive effect on reported subjective well-being. Furthermore, the coefficient for the two sub-indices for the right to change the canton's law or the

\footnotetext{
${ }^{21}$ If the fixed effect of this canton is omitted, the coefficient for direct democratic rights increases to 0.100.

${ }^{22}$ The correlation between the four sub-indices is shown in table II in the Appendix.
} 
canton's constitution with a legislative or constitutional popular initiative are largest. Thus, the possibility to put new questions on the political agenda is of special importance for the beneficial effects of direct democracy on citizens individual well-being.

In order to test for alternative explanations of the cross-regional differences in happiness, the effect of some aggregate control variables is estimated on its own as well as jointly with the institutional variable. Table 4 exhibits the results for the two macroeconomic variables "national income per capita" and "total tax burden", as well as for the two language variables "French speaking canton" and "Italian speaking canton". Equation (1) and equation (2) indicate that national income per capita does not influence happiness significantly, whether it is controlled for institutional differences or not. The same holds for the variable total tax burden in equations 3 and 4. As can be seen, the introduction of these two macroeconomic variables does not (much) affect the size and significance of the direct democracy variable. In contrast, the variables for majority language are significantly correlated with reported satisfaction with life, i.e. living in a French speaking canton means significantly lower happiness, whereas living in the Italian speaking canton Ticino means significantly higher reported subjective well-being (equation 5).

Table 4.

Sensitivity Analysis: Aggregate Control Variables

\begin{tabular}{|c|c|c|c|c|c|c|}
\hline \multirow[b]{2}{*}{ Variable } & \multicolumn{6}{|c|}{ Weighted ordered probit, std. err. adjusted to clustering in 26 cantons } \\
\hline & (1) & (2) & (3) & (4) & (5) & (6) \\
\hline (1) Demographic variables & yes & yes & yes & yes & yes & yes \\
\hline (2) Economic variables & yes & yes & yes & yes & yes & yes \\
\hline \multicolumn{7}{|l|}{ (3) Institutional variable } \\
\hline Direct democratic rights & & $\begin{array}{l}0.087 * * \\
(3.223)\end{array}$ & & $\begin{array}{l}0.084 * \\
(2.698)\end{array}$ & & $\begin{array}{l}0.080 * \\
(2.806)\end{array}$ \\
\hline \multicolumn{7}{|l|}{ (4) Macroeconomic conditions } \\
\hline $\begin{array}{l}\text { National income per capita } \\
\text { in canton (in } 1,000 \text { ) in } 1992\end{array}$ & $\begin{array}{l}-1.8 \mathrm{e}-4 \\
(-0.054)\end{array}$ & $\begin{array}{l}-0.004 \\
(-1.256)\end{array}$ & & & & \\
\hline $\begin{array}{l}\text { Total tax burden (index) } \\
\text { in canton in } 1992\end{array}$ & & & $\begin{array}{l}-0.002 \\
(-1.340)\end{array}$ & $\begin{array}{r}2.7 \mathrm{e}-4 \\
(0.171)\end{array}$ & & \\
\hline \multicolumn{7}{|l|}{ (5) Majority language } \\
\hline French speaking canton & & & & & $\begin{array}{l}-0.213 * * \\
(-3.554)\end{array}$ & $\begin{array}{l}-0.076 \\
(-1.123)\end{array}$ \\
\hline Italian speaking canton & & & & & $\begin{array}{l}0.073^{(*)} \\
(1.963)\end{array}$ & $\begin{array}{l}0.252 * * \\
(3.337)\end{array}$ \\
\hline Observations & 6134 & 6134 & 6134 & 6134 & 6134 & 6134 \\
\hline Prob $>$ F & 0.005 & 0.007 & $2.0 \mathrm{e}-4$ & 0.002 & 0.010 & 0.001 \\
\hline
\end{tabular}

Notes: see table 1. Coefficients with significance levels. T-values in parentheses.

Data sources: Leu, Burri and Priester (1997) and Swiss Federal Statistical Office (1997). 
However, the lower well-being in the French speaking cantons can to a large extent be explained by weaker direct democratic rights (equation 6). In equation (6) the coefficient of the institutional variable is almost unchanged and still significant $(\mathrm{p}<0.05)$. It can be concluded that the extent of direct democracy has a robust influence on happiness.

\subsection{Who Benefits from Direct Democracy?}

Are the beneficial effects of direct democracy restricted to some privileged groups? To investigate this important question of equality, we analyse the influence of direct democracy for groups of persons sharing common characteristics in regard to sex, education, employment status and income. Technically, interaction variables are included in the estimation equation, in addition to the demographic and economic variables. The interaction variables are the product of dummy variables for the personal characteristics and the index for direct democratic rights.

The benefits of direct democracy reaped by women are smaller than for men. However, the difference is not statistically significant. There is also no significant difference between the three levels of education and the five categories of employment status distinguished, i.e. the positive effect of direct democracy does not arise with the education classes and is not bound to a certain employment status. We have also analysed whether direct democracy raises the happiness of high income recipients, while not doing so for low income recipients. However, the interaction variables do not show any statistically significant differences. The positive effect of direct democracy on happiness thus does not arise with the income classes, according to our data and estimates.

Overall, direct democracy seems not to be used to discriminate against certain groups within society. Moreover, the benefits are distributed rather evenly among social classes. However, a large share of residents is formally excluded from participation in the direct democratic process, namely foreigners. In the next paragraph, it is argued that they can reap only part of the utility derived from direct democracy.

\subsection{Direct Democracy and Procedural Utility}

Do citizens derive procedural utility from being able to participate in the directly democratic process? To answer this question, it is crucial to note that political participation in initiatives and referenda is restricted to Swiss nationals; only they can reap the respective procedural utility. Foreigners, in contrast, have in general no political participation rights. However, they cannot be 
discriminated from the favourable outcome of direct democracy (outcome utility). As foreigners cannot reap procedural utility from political participation, they are hypothesised to gain less from direct democracy than Swiss citizens. This can be tested either by considering an interaction effect between direct democracy and being a foreigner or by running separate equations for foreigners and Swiss. ${ }^{23}$ The results for the latter test are shown in table $5 .^{24}$

Table 5.

Satisfaction with Life of Foreigners and Swiss in Switzerland in 1992

\begin{tabular}{|c|c|c|c|c|c|c|}
\hline \multirow[b]{2}{*}{ Variable } & \multicolumn{3}{|c|}{$\begin{array}{c}\text { Foreigners } \\
\text { Weighted ordered probit } \\
\text { Std. err. adjusted to } \\
\text { clustering in } 26 \text { cantons }\end{array}$} & \multicolumn{3}{|c|}{$\begin{array}{c}\text { Swiss } \\
\text { Weighted ordered probit } \\
\text { Std. err. adjusted to } \\
\text { clustering in } 26 \text { cantons } \\
\end{array}$} \\
\hline & Coefficient & t-value & $\begin{array}{l}\text { Marginal } \\
\text { effect } \\
\text { (score } 10)\end{array}$ & Coefficient & t-value & $\begin{array}{l}\text { Marginal } \\
\text { effect } \\
\text { (score } 10)\end{array}$ \\
\hline (1) Demographic variables & yes & & & yes & & \\
\hline (2) Economic variables & yes & & & yes & & \\
\hline \multicolumn{7}{|l|}{ (3) Institutional variable } \\
\hline Direct democratic rights & 0.035 & 0.951 & 0.010 & $0.098 * *$ & 3.270 & 0.034 \\
\hline Observations & 743 & & & 5391 & & \\
\hline Prob $>F$ & 0.002 & & & 0.006 & & \\
\hline
\end{tabular}

Notes: see table 1.

Data sources: Leu, Burri and Priester (1997).

In both equations, direct democratic rights have a positive effect on reported subjective wellbeing. However, direct comparison of the two coefficients for direct democratic rights suggests that foreigners benefit less than Swiss citizens in cantons in which the institutions of direct democracy are well developed. Moreover, there is no evidence that the Swiss majority in more directly democratic cantons uses its institutional possibilities to exploit the minority of foreigners.

The size of the procedural utility gained from being able to participate in the direct democratic process can also be assessed. Comparing the positive marginal effect for direct democracy of 3.4

\footnotetext{
${ }^{23}$ Two separate regressions allow different coefficients for the control variables of the sample for foreigners and for Swiss citizens and thus foster the ceteris paribus interpretation of the results of the institutional variable.

${ }^{24}$ The results for the former test (a weighted ordered probit estimation with clustering in cantons) are as follows: satisfaction with life $=\ldots-0.042(-0.283)$ being a foreigner $\ldots+0.097 * *(3.384) \mathrm{x}$ index for direct democratic rights - 0.067 (-1.699) $\mathrm{x}$ interaction term (index for direct democratic rights $\mathrm{x}$ being a foreigner), with $\mathrm{t}$-values in parenthesis. The coefficient for the index of direct democracy is positive and statistically highly significant. This effect accounts for everybody, whether a Swiss citizen or a foreigner. The interaction variable shows that foreigners are cet. par. relatively less happy compared to Swiss citizens in cantons in which the institutions of direct democracy are well developed. However, the positive effect accounting for everybody is not compensated. This suggests, firstly, that foreigners are still better off in a more direct democratic canton and, secondly, that procedural utility, in addition to outcome utility, is an important source of satisfaction related to direct democracy.
} 
percentage points for Swiss citizens with the marginal effect of 1.0 percentage points for foreigners suggests that two thirds of the gain in well-being is due to the application of a favourable process in political decision-making. ${ }^{25}$ Procedural utility, over and above outcome utility, is an important source of satisfaction due to direct democracy.

An alternative interpretation of these results can be advanced on the basis of the missing variables problem. Assuming that foreigners and Swiss citizens are equally affected by unobserved regional factors, the causal effect of direct democratic rights on happiness is identified by the difference in the coefficients for this variable between the two groups. ${ }^{26}$ According to this interpretation, the marginal effect of direct democratic rights on subjective well-being is slightly smaller, namely 3.4 minus 1.0 , i.e. 2.4 percentage points instead of 2.8 percentage points as estimated in table 1.

\section{Conclusions}

With data from interviews of more than 6,000 Swiss residents, we have adduced strong evidence that institutional (or constitutional) factors exert a systematic and sizeable influence on reported happiness. The existence of extended individual participation possibilities in the form of initiatives and referenda, and of decentralised (federal) government structures raises the subjective well-being of people.

The influence of these political institutions on happiness is consistent with the hypothesis that politicians in a strongly developed direct democracy are forced more to follow the preferences of the voters than when direct popular participation rights are less well developed. Moreover, the citizens gain procedural utility from the fuller possibilities to directly participate in the political process. Foreigners living in Switzerland are more likely to benefit from the outcome than from the process (from which they are excluded). We find indeed that foreigners tend to reap systematically positive but lower satisfaction from living in a canton with strongly developed direct participation rights than do the Swiss.

\footnotetext{
${ }^{25}$ Quantitatively very similar results are obtained if interaction terms for direct democratic rights and being Swiss and being foreigner, respectively, are included in one equation instead of estimating two separate regressions.

${ }^{26}$ This interpretation is analogous to the differences-in-differences estimator for time series as e.g. applied in Card (1990).
} 
These results, with respect to the institutional determinants of happiness, are obtained even if the "standard" determinants of happiness due to demographic and economic factors are controlled for, and a number of robustness checks are undertaken.

In consonance with other happiness studies, unemployment is associated with a considerably lower level of subjective well-being. A higher equivalence income has a statistically significant positive but small effect on happiness. 


\section{References}

Argyle, M. (1987). The Psychology of Happiness, London: Methuen.

Barro, R. J. (1997). Determinants of Economic Growth: A Cross-Country Empirical Study, Cambridge: MIT Press.

Blankart, C. B. (1998). 'Politische Ökonomie der Zentralisierung der Staatstätigkeit', Discussion Paper 108, Berlin: Humboldt-Universität.

Bohnet, I. and Frey B. S. (1999). 'Social Distance and Other-Regarding Behavior in Dictator Games: Comment', American Economic Review, vol 89(1), pp. 335-339.

Budge, I. (1996). New Challenge of Direct Democracy, Cambridge: Polity Press.

Card, D. E. (1990). 'The Impact of the Mariel Boatlift on the Miami Labor Market', Industrial and Labor Relations Review, vol. 43(2), pp. 245-257.

Clark, A. E. and Oswald A. J. (1994). 'Unhappiness and Unemployment', Economic Journal, vol. 104(424), pp. 648-659.

Costa, P. T. and McCrae R. R. (1988). 'Personality in Adulthood: A Six-Year Longitudinal Study of Self-Reports and Spouse Ratings on the NEO Personality Inventory', Journal of Personality and Social Psychology, vol. 54(5), pp. 853-863.

Cowell, F. A. (1990). Cheating the Government. The Economics of Evasion, Cambridge, M.A.: MIT Press.

Cronin, T. E. (1989). Direct Democracy. The Politics of Initiative, Referendum and Recall, Cambridge, MA: Harvard University Press.

Dasgupta, P. (1993). An Inquiry into Well-being and Destitution, Oxford, N.Y.: Oxford University Press.

Di Tella, R., MacCulloch R. J. and Oswald A. J. (1997). 'The Macroeconomics of Happiness', Discussion Paper No. 19, Centre for Economic Performance, University of Oxford.

Diener, E. (1984). 'Subjective Well-Being', Psychological Bulletin, vol. 95(3), pp. 542-575.

Diener, E., Diener M. and Diener C. (1995). 'Factors Predicting the Subjective Well-Being of Nations', Journal of Personality and Social Psychology, vol. 69(5), pp. 851-864. 
Diener, E. and Oishi S. (1999). 'Money and Happiness: Income and Subjective Well-Being Across Nations', In E. Diener and E. M. Suh, (eds) Subjective Well-Being Across Cultures, Cambridge, MA: MIT Press, forthcoming.

Diener, E., Suh E. M., Lucas R. E. and Smith H. L. (1999). 'Subjective Well-Being: Three Decades of Progress', Psychological Bulletin, vol. 125(2), pp. 276-303.

Dixon, H. D. (1997). 'Controversy: Economics and Happiness', Economic Journal, vol. 107(445), pp. 1812-1814.

Easterlin, R. A. (1974). 'Does Economic Growth Improve the Human Lot? Some Empirical Evidence', In P. A. David and M. W. Reder (eds) Nations and Households in Economic Growth: Essays in Honour of Moses Abramowitz, New York and London: Academic Press, pp. $89-125$.

Easterlin, R. A. (1995). 'Will Raising the Incomes of All Increase the Happiness of All?', Journal of Economic Behaviour and Organization, vol. 27(1), pp. 35-48.

Feld, L. and Kirchgässner G. (1996). 'Public Debt and Budgetary Procedures: Top Down or Bottom Up. Some Evidence from Swiss Municipalities', In J. M. Poterba and J. von Hagen (eds.) Fiscal Institutions and Fiscal Performance, Chicago: Chicago University Press, pp. 151-179.

Feld, L. P. and Savioz M. R. (1997). 'Direct Democracy Matters for Economic Performance: An Empirical Investigation', Kyklos, vol. 50(4), pp 507-538.

Frank, R. H. (1997). 'The Frame of Reference as a Public Good', Economic Journal, vol. 107(445), pp. 1832-1847.

Frey, B. S. (1991). 'Forms of Expressing Economic Discontent', In H. Norpoth, M. S. LewisBeck and J.-D. Lafay (eds) Economics and Politics. The Calculus of Support, Ann Arbor: University of Michigan Press, pp. 267-280.

Frey, B. S. (1994). 'Direct Democracy: Politico-Economic Lessons from Swiss Experience', American Economic Review, vol. 84(2), pp. 338-348.

Frey, B. S. (1997). 'A Constitution for Knaves Crowds Out Civic Virtues', Economic Journal, vol. 107(443), pp. 1043-1053. 
Frey, B. S. and Eichenberger R. (1999). The New Democratic Federalism for Europe. Functional Overlapping and Competing Jurisdictions, Cheltenham: Edward Elgar.

Gerber, E. (1999). The Populist Paradox: Interest Group Influence and the Promise of Direct Legislation, Princeton: Princeton University Press.

Headey, B. and Wearing, A. (1989). 'Personality, Life Events, and Subjective Well-Being: Toward a Dynamic Equilibrium Model', Journal of Personality and Social Psychology, vol. 57, pp. 731-739.

Hibbs, D. (1973). Mass Political Violence: A Cross-National Causal Analysis, New York.

Hibbs, D. (1976). 'Industrial Conflict in Advanced Industrial Societies', American Political Science Review, vol. 70(12), pp. 1033-1058.

Kenny, C. (1999). 'Does Growth Cause Happiness, or Does Happiness Cause Growth?', Kyklos, vol. 52(1), pp. 3-26.

Kölz, A. (1998). Der Weg der Schweiz zum modernen Bundesstaat. Historische Abhandlungen, Chur and Zürich: Rüegger.

Ladner, A. (1994). 'Finanzkompetenzen der Gemeinden - ein Überblick über die Praxis', In F. Eng, A. Glatthard and B. H. Koenig (eds) Finanzföderalismus, Bern: Emissionszentrale der Schweizer Gemeinden, pp. 64-85.

Leu, R. E., Burri S. and Priester T. (1997). Lebensqualität und Armut in der Schweiz, Bern: Haupt.

Lucas, R. E., Diener E. and Eunkook S. (1996). 'Discriminant Validity of Well-Being Measures', Journal of Personality and Social Psychology, vol. 71(3), pp. 616-628.

Makin, J. H. (1976). 'Constraints on Formulation of Models for Measuring Revealed Preferences of Policy Makers', Kyklos, vol. 29(4), pp. 709-732.

Matsusaka, J. G. (1995). 'Fiscal Effects of the Voter Initiative: Evidence from the Last 30 Years', Journal of Political Economy, vol. 103(3), pp. 587-623.

Moulton, B. R. (1990). 'An Illustration of a Pitfall in Estimating the Effects of Aggregate Variables on Micro Units', Review of Economics and Statistics, vol. 72(2), pp. 334-338.

Myers, D. G. (1993). The Pursuit of Happiness: Who Is Happy and Why?, New York: Avon. 
Nannestad, P. and Paldam M. (1994). 'The VP-function: A Survey of the Literature on Vote and Popularity Functions after 25 Years', Public Choice, vol. 79(3-4), pp. 213-245.

Ng, Y. K. (1997). 'A Case for Happiness, Cardinalism, and Interpersonal Comparability', Economic Journal, vol. 107(445). pp. 1848-1858.

Opp, K.-D. (1989). The Rationality of Political Protest, A Comparative Analysis of Rational Choice Theory, Boulder: Westview Press.

Opp, K.-D., Voss, P. and Gern, C. (1995). The Origins of a Spontaneous Revolution. East Germany 1989, Ann Arbor: Michigan University Press.

Oswald, A. J. (1997). 'Happiness and Economic Performance', Economic Journal, vol. 107(445), pp. $1815-1831$.

Pommerehne, W. W. (1978). 'Institutional Approaches to Public Expenditure: Empirical Evidence from Swiss Municipalities', Journal of Public Economics, vol. 9(2), pp. 225-280.

Pommerehne, W. W. (1990). 'The Empirical Relevance of Comparative Institutional Analysis', European Economic Review, vol. 34(2-3), pp. 458-469.

Pommerehne, W. W. and Weck-Hannemann H. (1996). 'Tax Rates, Tax Administration and Income Tax Evasion in Switzerland', Public Choice, vol. 88(1-2), pp. 161-170.

Rueben, K. (1999). 'Tax Limitations and Government Growth: The Effect of State Tax and Expenditure Limits on State and Local Government', Journal of Political Economy, forthcoming.

Sandvik, E., Diener E. and Seidlitz, L. (1993). 'Subjective Well-Being: The Convergence and Stability of Self-Report and Non-Self-Report Measures', Journal of Personality, vol. 61(3), pp. $317-342$

Santerre, R. E. (1989). 'Representative versus Direct Democracy: Are there Any Expenditure Differences?', Public Choice, vol. 60(2), pp. 145-154.

Santerre, R. E. (1993). 'Representative versus Direct Democracy: The Role of Public Bureaucrats', Public Choice, vol. 76(3), pp. 189-198. 
Schneider, F. and Frey B. S. (1988). 'Politico-Economic Models of Macroeconomic Policy: A Review of the Empirical Evidence', In T. D. Willett (ed.) The Political Economy of Money, Inflation and Unemployment, Durham and London: Duke University Press, pp. 240-275.

Schneider, F. and Pommerehne W. W. (1983). 'Macroeconomia della crescita in disequilibrio e settore pubblico in espansione: il peso delle differenze istituzionali', Rivista Internazionale di Scienze Economiche e Commerciali, vol. 33(4-5), pp. 306-320.

Stutzer, A. (1999). 'Demokratieindizes für die Kantone der Schweiz', IEW Working Paper No. 23, Institute for Empirical Research in Economics, University of Zurich.

Swiss Federal Statistical Office (ed.) (1997). Statistisches Jahrbuch der Schweiz. Zürich: Neue Zürcher Zeitung.

Thomas, J. J. (1992). Informal Economic Activity, London: Wheatsheaf.

Trechsel, A. and Serdült U. (1999). Kaleidoskop Volksrechte: Die Institutionen der direkten Demokratie in den schweizerischen Kantonen 1970-1996, Basel, Genf, München: Helbing \& Lichtenhahn.

Tyler, T. R. (1990). Why People Obey the Law, New Haven: Yale.

Veenhoven, R. (1993). Happiness in Nations: Subjective Appreciation of Life in 56 Nations 1946-1992, Rotterdam: Erasmus University Press.

Veenhoven, R. (1999). 'Freedom and Happiness. A Comparative Study in 44 Nations in the Early 1990's', In E. Diener and E. M. Suh (eds) Subjective Well-Being Across Cultures, Cambridge, MA: MIT Press, forthcoming.

Wilson, W. (1967). 'Correlates of Avowed Happiness', Psychological Bulletin, vol. 67(4), pp. 294-306.

Winkelmann, L. and Winkelmann R. (1998). 'Why Are the Unemployed So Unhappy? Evidence from Panel Data', Economica, vol. 65(257), pp. 1-15. 
Appendix

\section{Index for direct democratic rights and local autonomy in Swiss cantons}

Direct democracy is here defined in terms of individual political participation possibilities. In Switzerland, institutions for the direct political participation of citizens exist on the level of the federal state as well as on the level of cantons. However, the direct democratic rights on the level of cantons are very heterogeneous. Therefore, an index is constructed to measure the different barriers to citizens entering the political process, apart from elections in the year 1992. The index is based mainly on data collected in Trechsel and Serdült (1999) (for details see Stutzer 1999).

The four main legal instruments directly influencing the political process in Swiss cantons are
a) the popular initiative to change the canton's constitution,
b) the popular initiative to change the canton's law,
c) the compulsory and optional referendum to prevent new law or changing law and
d) the compulsory and optional referendum to prevent new state expenditure.

Barriers are in terms of

a) the necessary signatures to launch an instrument (absolute and relative to the number of citizens with the right to vote),

b) the legally allowed time span to collect the signatures and

c) the level of new expenditure per head allowing a financial referendum.

(Compulsory referenda are treated like referenda with the lowest possible barrier.)

Each of these restrictions is evaluated on a six point scale: "one" indicates a high barrier, "six" a low one. From the resulting ratings, a non-weighted average is calculated for each instrument (i.e. four sub-indices) and for the composite index, which represents the measure of direct democratic rights in Swiss cantons. The results are presented in table I.

The index for local autonomy is based on survey results by Ladner (1994). Chief local administrators in 1856 Swiss municipalities reported how they perceive their local autonomy on a 10 point scale, with one indicating "no autonomy at all", and 10 "very high" communal autonomy. Average scores for each canton are also shown in table I. 
Table I.

Index for Direct Democratic Rights and Local Autonomy in Swiss Cantons

\begin{tabular}{|c|c|c|c|c|c|c|}
\hline \multirow[t]{2}{*}{ Canton } & \multicolumn{5}{|c|}{ Direct democracy } & \multirow[t]{2}{*}{ Local autonomy } \\
\hline & $\begin{array}{c}\text { Index for } \\
\text { constitutional } \\
\text { initiative }\end{array}$ & $\begin{array}{l}\text { Index for } \\
\text { legislative } \\
\text { initiative }\end{array}$ & $\begin{array}{l}\text { Index for } \\
\text { legislative } \\
\text { referendum }\end{array}$ & $\begin{array}{l}\text { Index for } \\
\text { financial } \\
\text { referendum }\end{array}$ & $\begin{array}{l}\text { Composite index } \\
\text { for direct } \\
\text { democratic rights }\end{array}$ & \\
\hline$\overline{\text { Aargau }}$ & 5.67 & 5.67 & 6.00 & 4.50 & 5.46 & 4.9 \\
\hline Appenzell i. Rh. & 6.00 & 6.00 & 6.00 & 3.00 & 5.25 & 5.0 \\
\hline Appenzell a. Rh. & 6.00 & 6.00 & 6.00 & 4.00 & 5.50 & 5.8 \\
\hline Bern & 2.67 & 2.67 & 3.67 & 5.00 & 3.50 & 4.6 \\
\hline Basel Land & 6.00 & 6.00 & 6.00 & 4.75 & 5.69 & 4.3 \\
\hline Basel Stadt & 4.67 & 4.67 & 4.00 & 4.25 & 4.40 & 5.5 \\
\hline Fribourg & 2.67 & 2.67 & 2.33 & 2.00 & 2.42 & 4.2 \\
\hline Genève & 2.00 & 2.00 & 2.00 & 1.00 & 1.75 & 3.2 \\
\hline Glarus & 6.00 & 6.00 & 6.00 & 4.00 & 5.50 & 5.6 \\
\hline Graubünden & 4.00 & 5.00 & 6.00 & 4.00 & 4.75 & 5.8 \\
\hline Jura & 4.67 & 4.67 & 3.00 & 2.50 & 3.71 & 4.0 \\
\hline Luzern & 4.67 & 5.33 & 3.67 & 4.25 & 4.48 & 4.1 \\
\hline Neuchâtel & 2.67 & 2.67 & 1.67 & 1.50 & 2.13 & 3.7 \\
\hline Nidwalden & 2.67 & 6.00 & 6.00 & 5.00 & 4.92 & 5.5 \\
\hline Obwalden & 5.33 & 6.00 & 6.00 & 5.00 & 5.58 & 6.0 \\
\hline Sankt Gallen & 3.33 & 4.00 & 3.00 & 3.25 & 3.40 & 4.9 \\
\hline Schaffhausen & 5.33 & 5.33 & 5.17 & 4.50 & 5.08 & 6.1 \\
\hline Solothurn & 5.33 & 5.33 & 6.00 & 5.00 & 5.42 & 4.9 \\
\hline Schwyz & 5.33 & 5.33 & 4.67 & 4.38 & 4.93 & 4.6 \\
\hline Thurgau & 3.67 & 3.67 & 4.33 & 4.50 & 4.04 & 5.9 \\
\hline Ticino & 1.33 & 2.67 & 1.67 & 2.75 & 2.10 & 4.3 \\
\hline Uri & 5.67 & 5.67 & 5.33 & 5.00 & 5.42 & 5.4 \\
\hline Vaud & 2.33 & 2.33 & 2.00 & 3.00 & 2.42 & 4.7 \\
\hline Valais & 3.00 & 3.67 & 6.00 & 1.00 & 3.42 & 5.5 \\
\hline Zug & 5.00 & 5.00 & 3.67 & 4.00 & 4.42 & 6.0 \\
\hline Zürich & 3.33 & 3.33 & 6.00 & 4.00 & 4.17 & 5.4 \\
\hline
\end{tabular}

Source: Ladner (1994) and own calculations on the basis of Trechsel and Serdült (1999). 
Table II.

Correlation of Sub-indices and Composite Index for Direct Democratic Rights and Local Autonomy in Swiss Cantons

\begin{tabular}{|c|c|c|c|c|c|c|}
\hline & CI & $\overline{\mathrm{LI}}$ & $\overline{\mathrm{LR}}$ & $\overline{\overline{F R}}$ & $\begin{array}{l}\text { DDR } \\
\end{array}$ & $\overline{\mathrm{LA}}$ \\
\hline $\begin{array}{l}\text { Index for constitutional } \\
\text { initiative (CI) }\end{array}$ & 1.000 & & & & & \\
\hline $\begin{array}{l}\text { Index for legislative } \\
\text { initiative (LI) }\end{array}$ & 0.871 & 1.000 & & & & \\
\hline $\begin{array}{l}\text { Index for legislative } \\
\text { referendum (LR) }\end{array}$ & 0.669 & 0.772 & 1.000 & & & \\
\hline $\begin{array}{l}\text { Index for financial } \\
\text { referendum (FR) }\end{array}$ & 0.539 & 0.632 & 0.562 & 1.000 & & \\
\hline $\begin{array}{l}\text { Composite index for direct } \\
\text { democratic rights (DDR) } \\
\text { Local autonomy (LA) }\end{array}$ & $\begin{array}{l}0.888 \\
0.410\end{array}$ & $\begin{array}{l}0.943 \\
0.506\end{array}$ & $\begin{array}{l}0.877 \\
0.646\end{array}$ & $\begin{array}{l}0.767 \\
0.531\end{array}$ & $\begin{array}{l}1.000 \\
0.605\end{array}$ & 1.000 \\
\hline
\end{tabular}

Table III.

Sensitivity Analysis: DFBETA-Test for 26 Swiss Cantons Independent variable: direct democratic rights

\begin{tabular}{llllrc}
\hline \hline Omitted observation & \multicolumn{1}{c}{$\beta_{0}$} & DFBETA & Omitted observation & $\beta_{0}$ & DFBETA \\
\hline Aargau & $0.078^{*}$ & 0.030 & Nidwalden & $0.079^{* *}$ & 0.007 \\
Appenzell i. Rh. & $0.079^{* *}$ & -0.007 & Obwalden & $0.073^{* *}$ & 0.264 \\
Appenzell a. Rh. & $0.073^{* *}$ & 0.241 & Sankt Gallen & $0.082^{* *}$ & -0.108 \\
Bern & $0.081^{* *}$ & -0.072 & Schaffhausen & $0.083^{* *}$ & -0.161 \\
Basel Land & $0.088^{* *}$ & -0.325 & Solothurn & $0.081^{* *}$ & -0.049 \\
Basel Stadt & $0.078^{* *}$ & 0.065 & Schwyz & $0.078^{* *}$ & 0.062 \\
Fribourg & $0.073^{*}$ & 0.217 & Thurgau & $0.079^{* *}$ & 0.025 \\
Genève & $0.080^{* *}$ & -0.035 & Ticino & $0.100^{* *}$ & -0.829 \\
Glarus & $0.080^{* *}$ & -0.027 & Uri & $0.077^{* *}$ & 0.073 \\
Graubünden & $0.080^{* *}$ & -0.025 & Vaud & $0.058^{*}$ & 0.775 \\
Jura & $0.079 * *$ & 0.002 & Valais & $0.080^{* *}$ & -0.024 \\
Luzern & $0.084^{* *}$ & -0.186 & Zug & $0.078^{* *}$ & 0.042 \\
Neuchâtel & $0.075^{*}$ & 0.139 & Zürich & $0.082^{* *}$ & -0.117 \\
\hline \hline
\end{tabular}

Notes: A value of DFBETA greater than 1.96 in absolute value shows an influential observation. Weight: inverse of the number of observations per canton. Significance levels: $\left.{ }^{*}\right) 0.05<\mathrm{p}<0.10, * 0.01<\mathrm{p}<0.05, * * \mathrm{p}<0.01$.

Data sources: Leu, Burri and Priester (1997). 